\title{
Sob o signo das aparências: indumentária urbana carioca da primeira metade do século $\mathrm{XX}$
}

Under the sign of appearances: urban carioca clothing in the first half of the 20th century

Resenha de: VOLPI, Maria Cristina. Estilo urbano: modos de vestir na primeira metade do século XX no Rio de Janeiro. São Paulo: Estação das Letras e Cores, 2018. 
LAURA FERRAZZA DE LIMA ${ }^{1}$

ORCID: http://orcid.org/0000-0001-8005-0494

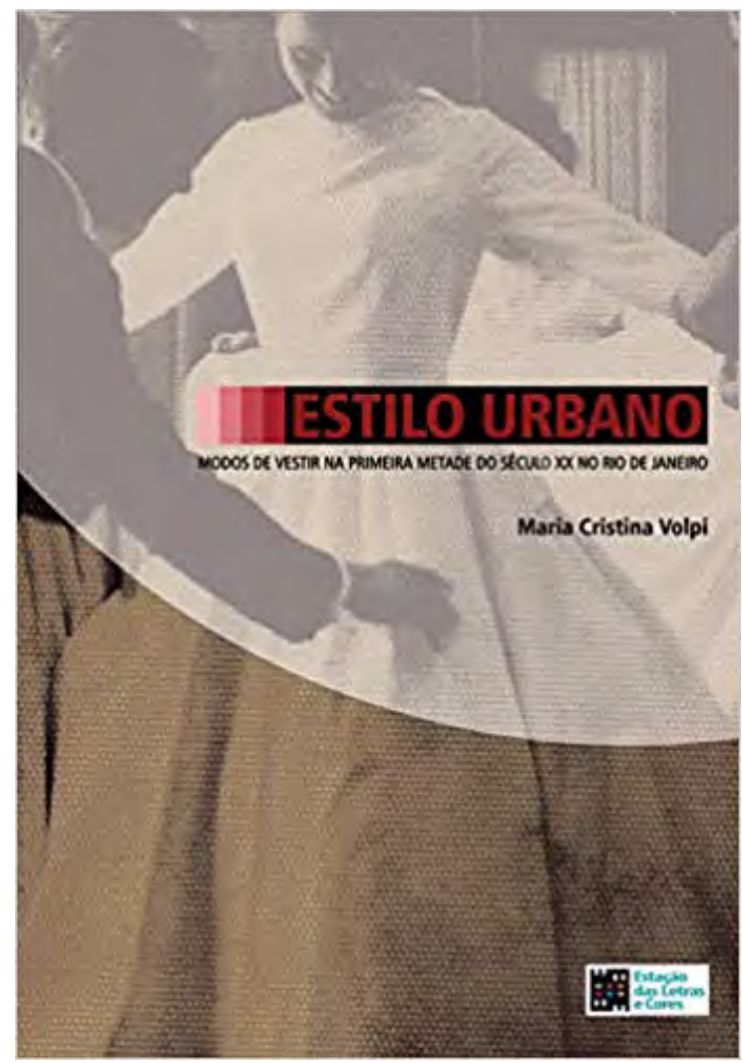

A professora e pesquisadora Maria Cristina Volpi nos apresenta em seu livro Estilo urbano: modos de vestir na primeira metade do século XX no Rio de Janeiro um estudo que relaciona moda, classe social e cultura material. 0 texto adaptado de sua tese de doutorado pela Universidade Federal Fluminense, apresenta grande potencial para servir como suporte teórico-metodológico para diferentes áreas de pesquisa que envolvam o vestuário. Partindo de um caso particular - a observação de um conjunto de fotografias que acompanha as mudanças no vestuário de uma família burguesa carioca durante cinquenta anos -, ela analisa a circulação dos códigos de representação social expressos pelas vestimentas.

A diversidade das fontes foi definida segundo os preceitos de Roland Barthes (1981) sobre os três níveis de manifestação do vestuário. Para reconstituir o vestuário escrito a autora utilizou manuais de etiqueta, no melhor estilo Norbert Elias (1993), considerando o traje como parte do processo civilizador humano. Aos manuais de etiqueta uniu os manuais

\footnotetext{
1 Pós-doutora em História pela UFRGS.

E-mail: laura_de_lima@yahoo.com.br. Lattes: http://lattes.cnpq.br/1622386303198860.
} 
de corte e costura, que apresentam a descrição técnica da construção material dos trajes. Utilizou ainda relatos orais transcritos dos proprietários da coleção fotográfica.

A inovação é patente pela utilização dos manuais tanto de etiqueta como de corte e costura, ricas fontes ainda pouco utilizadas nas pesquisas sobre vestuário no Brasil, além da variedade de tipos de fontes, todas muito bem especificadas em seu uso e função dentro da pesquisa. Os manuais são evocados principalmente no segundo capítulo, que visa analisar os meios e códigos de comportamento presentes nos manuais de etiqueta, assim como as regras do bem vestir. A adesão de determinados grupos a tais regras sociais ajudaria a acentuar as distinções de classe.

Para a análise do chamado "vestuário real" a autora propõe a observação das transformações técnicas na fabricação das roupas, possível de ser observada graças aos acervos de indumentária que ela consultou principalmente no Rio de Janeiro, nos lembrando da importância dessas coleções de trajes e indicando como trabalhar com a cultura material nas pesquisas sobre vestuário. Assim, a pesquisa reforça as relações entre os estudos da cultura material e dos comportamentos sociais.

A fim de analisar o que Barthes chamou de "vestuário imagem", aparece o acervo fotográfico pertencente a um dos ramos da família da própria autora. Chama a atenção o rigor metodológico e o desenvolvimento de quadros analíticos e de fichas de catalogação feitos para melhor mapear o corpus documental, e que podem servir de modelo para outros pesquisadores. Volpi faz transcender o estudo de caso, e nos lembra que nos álbuns de retratos guardados, quem sabe, por nossas mães e avós podemos encontrar um rico e denso material para pesquisa.

No capítulo de abertura Maria Cristina Volpi apresenta uma rica relação de diversas correntes teóricas que faz convergir na direção de seus objetivos de pesquisa. Os objetivos de sua pesquisa são: verificar a alteração no padrão vestimentar, a interiorização e circulação dos novos padrões e a manutenção dos códigos de representação social através do vestuário das camadas médias urbanas ao longo de cinquenta anos. Para atingi-los ela analisa uma fração do todo social através do caso das fotografias de uma família pertencente à burguesia média carioca do período delimitado.

Durante suas elucubrações teóricas, a autora nos lembra do valor intrínseco que podemos encontrar no mundo das aparências e de sua importância simbólica na construção de diferenças sociais. Ao buscar reconstruir a história das formas vestimentares da primeira metade do século XX, ela observa o estabelecimento de uma narrativa através das roupas. Para analisar tal narrativa e o caráter simbólico do vestir a autora utiliza uma perspectiva teórica derivada da semiótica estruturalista, na qual percebe padrões comunicativos nas formas de vestir. Unida a essa visão, Volpi reconstrói importantes contribuições da história cultural para a reflexão do impacto causado na sociedade e na cultura pelos trajes. A pesquisadora constrói assim um importante percurso que vai da macroanálise até a observação em escala reduzida da experiência familiar expressa no conjunto de fotografias escolhido como fonte. Demonstra, portanto, o caráter interdisciplinar das pesquisas em torno do vestir ao unir áreas da história, da antropologia e da análise de imagens. 
A autora entende que a fotografia, nesse caso, serve como plataforma de observação dos códigos de comportamento que orientam o bem vestir e fornecem sentido e espessura ao mundo das aparências. Ela define o vestuário como fato antropológico universal, considerando que em todas as sociedades humanas antigas e contemporâneas o traje e os adornos estão presentes. Dessa maneira, podemos atribuir ao ato de vestir um certo caráter ancestral. Afinal, vestir-se demonstra a ação do homem sobre o corpo e ajuda a compreender a função simbólica atribuída por ele a esse corpo. Além disso, o vestuário ajuda a estabelecer a relação entre o corpo humano e o meio natural e cultural unindo aspectos práticos e simbólicos. Através dessa linha argumentativa, Volpi nos lembra que a função do vestir vai muito além de cobrir e proteger o corpo, mas está repleta de grande carga simbólica.

No terceiro capítulo, a autora apresenta um panorama sobre as formas de produção e a transformação da cadeia produtiva dos objetos que compõem a indumentária. $\mathrm{O}$ foco no desenvolvimento e no funcionamento da indústria e do comércio dos trajes no Rio de Janeiro na primeira metade do século XX, mais do que contextualizar, une o universo produtivo à intimidade das fotografias de família. Características técnicas como tipo de maquinário, tecidos e estrutura das peças do vestuário revelam de maneira profunda as relações entre a produção do vestuário e sua carga simbólica, uma vez que o resultado de todo esse processo é não apenas cobrir um corpo, mas defini-lo simbolicamente, atribuindo-lhe forma, função e sentido social e cultural.

No capítulo final a autora nos apresenta um retrato da cidade do Rio de Janeiro no período abordado, relacionando a urbanidade e a moda. Ao evocar os espaços e as práticas de sociabilidade da burguesia média carioca, nos aproximamos da família que tem sua trajetória reconstruída pela análise das fotografias e dos trajes nelas expressos. Volpi utiliza a história de uma trajetória familiar que serve de cenário para observar em detalhe a história das formas vestimentares em ação.

\section{Referências}

BARTHES, Roland. 0 sistema da moda. Lisboa: Ed. 70, 1981.

ELIAS, Norbert. 0 processo civilizador. Tradução Ruy Jungmann. Rio de Janeiro: Zahar, 1993. $2 \mathrm{v}$. 